\title{
The preference for carbohydrate or protein is affected by the feeding status in post-weaned piglets
}

\author{
S. A. Guzmán-Pino, J. Figueroa, D. Solà-Oriol and J. F. Pérez \\ Animal Nutrition, Management and Welfare Research Group, Faculty of Veterinary Medicine, Universitat Autònoma \\ de Barcelona, Barcelona, Spain
}

Pigs, like other mammals, have a complex biological system that allows them to control their voluntary feed intake and self-nourishment in accordance to different physiological states ${ }^{(1)}$. The integration by the central nervous system of multiple signals arising from organs and tissues depending on feeding status may result in different response of pigs towards different nutrients, basically as a preference or an aversion $^{(2)}$. The aim of the present study was to assess whether the preference for a carbohydrate or protein source is affected by the feeding status (fasted or satiated) in post-weaned piglets.

A total 120 post-weaned piglets (56 days old) were distributed according to body weight into 12 pens (10 piglets/pen) and fed with a commercial weanling diet. On days $28,29,35$ and 36 after weaning those animals were submitted to an alternated sequence of ad libitum feeding or $4 \mathrm{~h}$ fasting. At the same days, the preferences for a carbohydrate (sucrose $0.0292 \mathrm{~mol} / \mathrm{l}$ ) or protein (porcine digestible peptides (PDP, Palbio 62SP ${ }^{\circledR}$ ) $20 \mathrm{~g} / \mathrm{l}$ ) solutions were evaluated by using a double-choice test (DCHT) protocol. Two different bottles (5 litres) were simultaneously offered for a period of $5 \mathrm{~min}$. Solution intakes and the corresponding preference values (measured as the percentage contribution of this solution to the total volume intake) were analyzed with ANOVA. Preference values were also compared to the neutral value of $50 \%$ by using a Student's $t$-test.

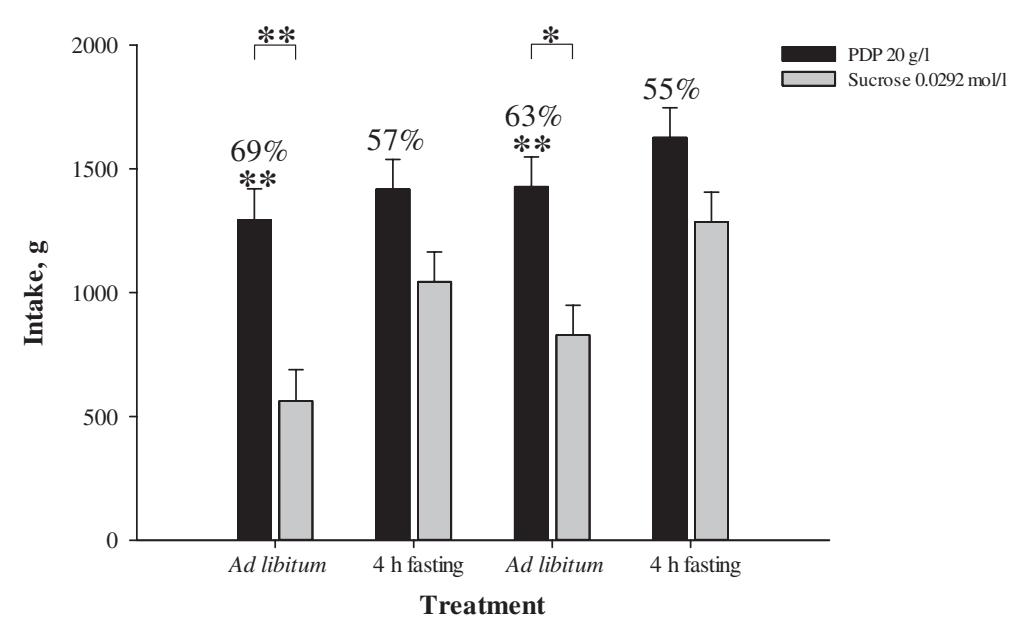

When piglets had free access to feed they showed a higher volume intake (clasps, $* P<0.05, * * P<0.01$ ) and preference (numbers on top of the bars, $* * P<0.01)$ for the PDP solution than for sucrose solution, while no significant preference $(P>0.05)$ was observed for the tested solutions when piglets were fasted for a period of $4 \mathrm{~h}$. These results show that weanling piglets may change their preferences for a carbohydrate or a protein source depending on the feeding status.

1. Forbes JM (1998) Appl Anim Behav Sci 57, 287-297.

2. Myers KP (2007) Appetite 48, 123-127. 